extremely simple. It is composed (Fig. I) of two metallic plates, $R, R$, forming springs, and separated by a small piece of fusible metal, $\mathrm{S}$, which is isolated from the plates by paper, or any other isolating body. The heat caused by the fire melts the metal, and the plates coming into contact, the electric acts upon the automatic supply-cock. This self-acting supply-cock (Fig. I) is composed of an electro-magnet, $M$, which, under the action of the current, becomes active, and attracts the arm $\mathrm{N}$, thus setting free the lever, $\mathrm{E}$. The weight, $\mathrm{F}$, then turns from right to left, and, after describing the quarter of a circle, falls upon the lever, $\mathrm{H}$, whilst the part, $\mathrm{G}$, removes a check which has kept the lever, $\mathrm{P}$, in position. Under the action of the weight, F, and by means of the lever, $\mathrm{P}$, which has its fulcrum in the point, $J$, the supply-cock, $C$, is turned, and the water rushes into the pipe, $A$, to be discharged above. The cock at B, which is worked by band, serves to stop the supply when the fire is extinguished, or when repairs are being made. Under ordinary circumstances, it must be always open, else the action of the automatic supplycock would be of no effect.

The water pouring upwards into the pipes ought to be discharged at the point where the fire appears. Ordinary perforated pipes may be used, but it is preferable to localise the discharge of water by the explosion of guncotton. This is produced (Fig. 2) either by the inflammation of very combustible strings $\mathrm{K}$, which set fire through $\mathrm{D}$ to some gun-cotton placed in the small pistons $\mathrm{B}$; or elestrically (Fig. 3) by a fine platinum wire $\mathrm{N}$ being rendered incandescent by the current, and thus exploding the gun-cotton. For this purpose the two conducting wires $O$ and $P$ are separated by an insulating combustible matter and a fusible conductor, resembling those of $M$. Charpentier. The increase of temperature accordingly completes the circuit and causes the explosion. When there is no public supply of water, as in small towns, $M$. Maxi $n$ would then utilise the electric current as follows :The weight F (Fig. I) when set free falls on a bottle of sulphuric asid placed over a reservoir balf filled with water, containing a certain proportion of lime. A large quantity of carbonic acid being thus produced in a closed reservoir, the pressure forces the water inio the system of pipe;. Fig. 4, the section of a large theatre, shows how the system of pipes may be disposed around the stage. Such, substantially, are the principles of M. Maxim's apparatus for preventing fires in theatres and places where people assemble in numbers, such as large warehouses, hotels, \&c.

Taking the most impartial view of the advantages to be gained by this apparatus, we hope it will soon be submitted to the test of experience, while desiring there may never be any occasion of making its effectiveness too prominent.

\section{ART METAL WORK OF JAPAN}

FOR centuries past the artists of Japan have earned for themselves a reputation for their skill in the working of metals, and at the present day their productions in bronze, iron and steel, excite admiration and astonishment. This art industry is of extreme antiquity. Mr. Satow, in his recent handbook of Central and Northern Japan, describes the colossal image of Buddha at Nara It was first cast in 749 A.D., and was set up in its present position. It suffered from various accidents, and in 1567 the temple was burned to the ground, the bead of the image falling off. It was replaced not long afterwards, and we may therefore assign to the body an age of II 40 years, and to the head about 300 years. Buddha is represented seated cross-legged on a dais which is of bronze, and represents the calyx of a lotus. The figure is $53 \frac{1}{2}$ feet high; the face is 16 feet long, and $9 \frac{1}{2}$ wide, while 966 curls adorn the head, around which is a halo 78 feet in diameter, on which are images 8 feet in length. A roof protects the image, and a staging is erected to assist visitors in examining it. The casting is said to have been attempted seven times before it was accomplished, and 3000 tons of charcoal were used in the operation. The whole is said to weigh 450 tons, and the alloy is composed of :-

$$
\begin{array}{lllllrl}
\text { Gold } & \ldots & \ldots & \ldots & \ldots & 500 & \text { lbs. } \\
\text { Mercury } & \ldots & \ldots & \ldots & \ldots & 1,954 & " \\
\text { Tin } & \ldots & \ldots & \ldots & \ldots & \text { r6,827 } ", \\
\text { Copper } & \ldots & \ldots & \ldots & \ldots & 986,080 & ,
\end{array}
$$

"The body of the image and all the most ancient part of the lotus flowers on which it is seated are apparently formed of plates of bronze ro inches by I 2 , soldered together, except the modern parts, which are much larger castings. A peculiar method of construction is said to have been adopted, namely, of gradually building up the walls of the mould as the lower part of the casting cooled, instead of constructing the whole mould first, and then making the casting in a single piece." The other large image of Dai Butsu at Kamakura, near Yokohama, is somewhat smaller than this, and dates from a period three centuries more recent. The various temple bells, some of which are of great size, are remarkable for the sweetness and mellowness of their tones, which contrast greatly with the harsh, clanging sounds to which we are accustomed in Europe. They are struck on the outside by huge pine beams which are suspended by strong ropes. The vessels ordinarily used in worship, such as vases, lamps, and incense-burners, are also of bronze, many of them being fine specimens of art, executed in high relief, and finished with much care. The demand for art metal work of a high order has thus existed for centuries in Japan; and so far as can be judged from the specimens of more modern work of this description, the hand of the Japanese workman has not lost its cunning. In the Japanese Art-Gallery in Grafton Street, among many rare and beautiful productions of the Land of the Rising Sun, the metal work well deserves attention. A pair of dark green-tinted bronze vases, fourteen inches high, inlàid with gold, are conspicuous for beauty of design and workmanship. They are said to have occupied the maker seven years, and their curious tint is said to be a trade secret. It must be understood that it is no mere surface colouring, but is produced by the mixture of the metals in certain proportions. The work on the rims and necks represent in gold inlay a cloud dragon, while the bodies are decorated with four medallions formed of gold and silver inlays, the shading obtained by an inlay of gold upon silver being very remarkable. The tints of bronzes vary in colour and depth from yellow, green, and ruddy to dark brown, and next to beauty of design, the tint is a sine quâ non. A favourite design on bronzes is the dragon, a subject which is treated with much force an 1 character.

A plaque of Shakudo-an alloy of gold and copper, and black in colour-set in a bronze mounting, representing the bamboo, is remarkable as showing the care and labour expended by the Japanese artist in working out details. The design represents a meeting between the twelve chief disciples of Buddha; the inlaying of the figures, trees, flowers, \&c., is of gold and silver, with various tinted compositions, and stands out from the dark background of the alloy with much brilliancy. One of the compositions employed for shading is called shibu-ichi, and consists of three parts of copper to one of silver. Both these alloys are favourite compositions of the Japanese artist. The minute interlaying of gold and silver in another plaque, about eighteen inches in diameter, with a curvilinear border, exhibits marvellous skill. The body of the plaque is of iron, and the border is adorned with grape-leaf and fruit patterns, the former being of gold, the latter of silver. This is the work of Komai, of Kioto, whose fainily held the office of sword-mounters to the Court. Swords in the olden time 
were much prized by their owners, for the quality and temper of the steel, and much cost was lavished on the ornaments of the handles and sheaths. The making of a good sword was regarded as a very serious task, and the maker had to conform to certain rules of conduct from the commencement to the end of the operation. The external ornaments offered endless scope to the skill and care of the worker in metals. Great importance is attached to the maker's name, which is engraved above the guard. It was a common saying of the Japanese, that the swords of celebrated makers, such as Naminohira Yukiyasu, Masamune, and others, could not return to their scabbards, unless they had been dipped in blood; the sword maker's occupation is now gone, not so their fellow-artists, the sword-mounters. Their skill in working metals can always be turned to good account.

Many other works in metal in the gallery deserve mention, but we cannot refer to them here. They all exhibit the patience, skill, imagination, and love of his craft which distinguished the Japanese artist of old. It is to be feared that he is now abandoning these qualities, and seeking a more rapid road to fortune by shoddy foreign imitations, and that beautiful works requiring the patience and loving care of years-such, for instance, as the small cabinet shown in Grafton Street, which was made for the third Shôgun of the last dynasty, and which is probably the finest work of its kind in existence--will soon be things of the past.

\section{ELECTRICITY AT THE CRYSTAL PALACE} III. Land Telegraphy.

HAVING regard to the leading part played by our country in the rise and development of the telegraph, it was only to be expected that the display of historical apparatus at the Crystal Palace should be a very good one. Thanks to the antiquarian zeal of $\mathrm{Mr}$. W. H. Preece, F.R.S., and his active interest in all that pertains to the history of his profession, the Post Office has become the careful custodian of all the early telegraphs employed in England, and the stall of H.M. Postmaster General is rich in these relics of the past. Indeed, there is the nucleus here of an interesting museum of telegraphic apparatus; and it is to be hoped that such a museum will one day be established. The Society of Telegraph Engineers and Electricians have now their Ronald's Library of Electrical Works, which is practically open to all inquirers. A public museum of electrical appliances, rendered historical by the lapse of time, would be a supplementary institution of inestimable value.

One of the most interesting of these relics is the 1816 telegraph of Sir Francis Ronald himself, kindly lent by Mr. Latimer Clark, together with a portion of the copper conductor which Ronald threaded through a glass tube, protected by a wooden trough, and buried in his garlen at Hammersmith. It was a frictional electric telegraph, and indicated letters by the divergence of two pith balls, after a plan somewhat similar to the suggestion of "C.M." in the Scots Magazine for 1759. This device is fully described in Ronald's "Electrical Telegraph," I836, the first work published in England on the subject. A copy of this work is possessed by Mr. Latimer Clark, who we may also mention has lately acquired a forgotten book on the history of telegraphs (non-electrical), published in 1797 for the author, Mr. J. Gamble.

On August 5, 1816, the British Admiralty expressed their opinion to Sir Francis Ronalds that "telegraphs of any kind were then wholly unnecessary," and the invention of Ronalds was neglected. Nevertheless, being worked by static electricity, it is doubtful if it ever would have become a practical success. The "fossil" telegraph of Messrs. Cooke and Wheatstone, laid between Euston and Camden Town in 1837 , was the first practical telegraph in operation, and a specimen of it is shown by the
Post Cffice. The line was formed of copper wires covered with cotton and pitch, and inlaid in triangular lengths of wood, which were buried underground. It was worked in connection with Cooke and Wheatstone's Five Needle Telegraph, the parent of the present single and double needle instruments, now used in railway signalling.

Especiaily interesting also are the porcelain tubes employed by Samuel Morse as insulators, and the lead type, cast by that inventor as early as December, 1832, for his electromagnetic telegraph, now known as the Morse inker. The original Cooke and Wheatstone needle instruments, and the apparatus designed to compete with them, for example, Alexander Bain's I. and V. telegraph, in which the alphabet is formed by the movement of two pointers attached to circular magnets moving inside coils; the Highton gold leaf telegraph, in which a strip of gold leaf inclosed in a glass tube traverses the field of a permanent magnet, and forms part of the line-circuit. When a current passes through the leaf it moves to right or left, according to the polarity. Henley's Magneto Telegraph, the Wheatstone ABC instrument, and the Bell receiver of Sir Charles Bright, are also shown. This last appeals to the ear rather than the eye, by striking two bells of different pitch, and is the forerunner of the modern class of "sounders" which are superseding writing telegraphs on land-lines in America and England, owing to their clean and rapid working, and the ease with which a clerk can listen to the message and write it down at the same time.

Space would fail us if we were to refer to all the historical apparatus exhibited by the Post Office. There the visitor will be able to trace the development of the electric telegraph in this country from the earliest attempts, and on the same table he will see at work the latest improved apparatus for transmitting and receiving messages. The Wheatstone automatic instrument, which is capable of sending 200 words per minute, and is chiefly used for press intelligence, the American duplex, on the Morse system, and the Pneumatic Despatch, for forwarding written telegrams from St. Martins le Grand to local stations in the City, are all in operation.

Before leaving the Post Office stall we ought to mention an imported curiosity, which excited a great deal of interest when first displayed in the Norwegian Section of the recent Paris Electrical Exhibition, and to which we drew attention some months ago. This is a sample of a telegraph post from Norway, which has been pierced through and through by the beaks of the black and green Norwegian woodpeckers. Two of these marauders are stuffed and mounted on the perforated pole which is the witness to their strength of beak and perseverance. The explanation of the singular attack is that the birds, hearing the vibration of the wires as they tremble in the wind, mistake it for the hum of insects within the post, and courageously peck their way into the coveted feast. It matters not whether the timber is fresh or old; and I have been assured by a Norwegian telegraph engineer, that he has found several newly erected posts perforated in a single night. Bears in the mountain districts are also said to attack the foot of the posts, tooth and nail, under the impression that there are bees within; and after the experiments of Mr. C. V. Boys on the influence of tuning forks on spiders (see NATURE, vol. xxiii. p. I49), the deception of these animals is quite intelligible. The authenticated fact that wolves are scared away from whole districts in Norway on the appearance of a telegraph line there, is not so easily understood, unless it be that the wires are held to be some kind of snare. This explanation is supported by the custom of Norwegian farmers of running a cord on poles round their homesteads to keep off the wolves, and it is stated that an entire peninsula was kept clear of wolves by spanning its neck in this fashion. 